Arhe XVIII, 35/2021

UDK 111.852 Gadamer H.G.

DOI https://doi.org/10.19090/arhe.2021.35.203-223

Originalni naučni rad

Original Scientific Article

\author{
NIKOLA TATALOVIĆ ${ }^{1}$ \\ Univerzitet u Novom Sadu, Filozofski fakultet
}

\title{
GADAMEROVO „PONAVLJANJE“ MIMEZISA I
}

Sažetak: Istraživanje prati osnovne momente Gadamerove rehabilitacije pojma mimezis koji je od odlučujućeg značaja za izgradnju celine njegovog projekta filozofske hermeneutike. Istraživanje ukazuje na temeljne pretpostavke koje rukovode Gadamerovim vraćanjem „izvornom” smislu mimezisa. Analizirajući Gadamerovo razumevanje pojma igre, preobražaja u tvorevinu i vremenskog karaktera umetničkog dela, istraživanje nastoji da ukaže na temeljnu određenost Gadamerovog pojma mimezis platonističkom tradicijom, pre svega neoplatonizmom. U pogledu na platonistički postavljenu igru razumevanja mimezisa koja se kreće kroz sukob istine kao korespondencije i istine kao samoprikazivanja bitka, analize u konačnom pokazuju da je kod Gadamera na delu opetovanje, a ne ponavljanje mimezisa, te se ukazuje na nužnost napuštanja pojma istine ukoliko se zaista želi izvršiti ponavljanje mimezisa. Prvi deo istraživanja, prezentovan u ovome radu, ima za cilj provođenje najvećeg dela prethodno navedenih analiza kako bi se u drugom delu istraživanja obrazložio prethodno istaknuti zaključak u pogledu karaktera Gadamerovog pojma mimezisa.

Ključne reči: Gadamer, mimezis, prikaz, igra, umetnost, svečanost, ponavljanje, teorija

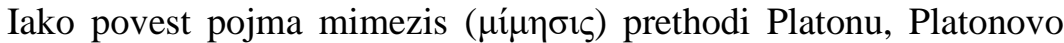
iskušavanje mimezisa ispostavlja se određujućim za svako potonje razumevanje ovoga pojma. Dato ne dolazi samo i pre svega zbog toga što je Platon navodnu izvornu dinamičku prirodu mimezisa, koja je svoje prvobitno poreklo imala u drami i kultnom plesu i kao takva značila

\footnotetext{
${ }^{1}$ E-mail adresa autora: nikolatatalovic@ff.uns.ac.rs
} 
izvođenje i prikazivanje ${ }^{2}$, transformisao $u$ statički smisao, tj. smisao zastupanja pretumačio u značenje kopiranja uzora i time odredio njegovu naknadnu povest razumevanja. ${ }^{3}$ Centralni značaj Platonovog promišljanja mimezisa za svu potonju povest dolazi pre svega od toga što niko ni pre ni posle njega nije sa tolikim naporom nastojao da pojmovno savlada ono što reč $\mu$ í $\rceil \sigma ı \varsigma$ imenuje. Moglo bi se čak reći da je Platon mislilac iskustva mimezisa.

Reći da je Platon mislilac iskustva mimezisa ne znači da je Platon u krajnjem ipak pojmovno savladao ono što mimezis sa sobom nosi - da je mimezis doveo do pojma, već da ga je tajna mimezisa uvek iznova pozivala na napor da je pojmovno odgonetne. Da je tako, svedoči i to da Platon ne samo da ne nudi jedinstveno određenje mimezisa, već da on uvek iznova daje različita određenja koja su često suprotstavljena. Pored prethodnog, sama kritika mimezisa provodi se u dijalozima kao par excellence mimetičkom žanru, što dovodi u pitanje karakter date kritike. Tako u Državi unutar 2. i 3. knjige Sokrat dopušta pravilnim uzorom kontrolisan mimetički proces obrazovanja, ${ }^{4}$ dok se u 10 . knjizi mimezis kao takav u celini kritikuje i odbacuje. ${ }^{5}$ Pored prethodnog, 10. knjiga Države kritikuje mimetičkog pesnika poredeći ga sa slikarem, ${ }^{6}$ dok Sokrat svoj govor o idealnom polisu prikazuje kao mimetičko delo slikara, ${ }^{7}$ a za filozofa vladara eksplicitno kaže da kao slikar podražava paradigmu države. ${ }^{8}$ Pored prethodnog, u dijalogu Kratil Platon kroz lik Sokrata eksplicitno odbacuje razumevanje mimetičke

\footnotetext{
${ }^{2}$ Koller, Hermann, Die Mimesis in der Antike. Nachahmung, Darstellung, Ausdruck, A. Francke, Berne, 1954, str. 37-48. Hans-Georg Gadamer se u vlastitom razumevanju mimezisa ekplicitno poziva na Kolerovu studiju (Gadamer, HansGeorg, Istina i metoda. Osnovi filozofske hermeneutike, prev. S. Novakov, Veselin Masleša, Sarajevo, 1978, str. 143). U pogledu kritike Kolerovog razumevanja izvornog misla mimezisa up. Else, Gerald F., "Imitation' in the Fifth Century", u: Classical Philology, Vol. 53, No. 2 (1958), str. 73-90.

${ }^{3}$ Keuls, Eva C., Plato and Greek Painting, Brill, Leiden, 1978., str. 12.

${ }^{4}$ Plat. Rep. 395b-d. Up. Popović, U., „Platonova kritika umetnosti iz perspektive obrazovanja", Arhe, VII, 13 (2010), str. 129-147.

${ }^{5}$ Plat. Rep. 595a-609d.

${ }^{6}$ Plat. Rep. 596e.

${ }^{7}$ Plat. Rep. $472 \mathrm{~d}$.

${ }^{8}$ Plat. Rep. 484c-d, 500c-e, 540a.
} 
slike po modelu kopiranja, tvrdeći da tako sačinjena mimetička slika Kratila ne bi bila slika Kratila, već još jedan Kratil, ${ }^{9}$ ali i više od toga. Sokrat ovde tvrdi da slikar može da podražava opšte tipove, te da matematička tačnost $i$ matematički smisao mere ne može biti primeren mimetičkoj slici, ${ }^{10}$ što je

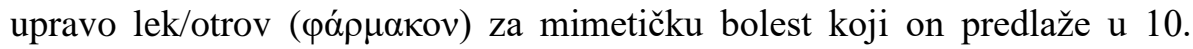
knjizi Države. ${ }^{11}$

Možemo zaključiti da ne postoji jedinstven pojam mimezisa kod Platona, tj. da na problem mimezisa ne postoji jedinstven odgovor. ${ }^{12}$ Mimezis kod Platona imenuje mrežu pojmova, slika, metafora i argumenata kojom se pokušava zahvatiti čitav niz odnosa: odnos umetničkog prikaza spram stvarnosti, odnos mišljenja i govorenja uopšte spram onoga što jeste, itd. Za Platona mimezis predstavlja područje problema i ukupnost veza koje ocrtavaju moguće relacije unutar sveta i unutar mišljenja, kao i relacije sveta i mišljenja. ${ }^{13}$ Rečju, mimezis za Platona ostaje ono što je bio od samog početka - mimezis ostaje problem. Platon i jeste mislilac mimezisa zato što nema jedan i jedinstveni pojam mimezisa. Time što uvek iznova stvara različita određenja mimezisa Platon zapravo potvrđuje nemogućnost kontrole mimezisa kao jedinu njegovu odliku, a time i umetnost samu u njenoj nesvodivosti na filozofski pojam.

No, ako je tako, ako je Platon zahvatio moć mimezisa ne tako što ga je pojmio i time uspostavio vlast filozofije nad umetnošću, već time što ga je kožom iskušao u njegovom odbijanju svakog svojstva i same ideje

\footnotetext{
${ }^{9}$ Plat. Crat. 432 b-c.

${ }^{10}$ Plat. Crat. 432 d.

${ }^{11}$ Plat. Rep. 602d.

12 Gonzalez, Francisco J., "The Philosophical Use of Mimēsis", u: The Many Faces of Mimessis. Selected Essays from the 2017 Symposium on the Hellenic Heritage of Western Greece, Heather L. Reid, Jeremy C. DeLong (ur.), Parnassos Press, Sioux City, 2018., str. 23-36, 32. Halliwell, Stephen, "Plato and Painting", u: Word and Image in Ancient Greece, N. K. Rutter, B. A. Sparkes (ur.), Edinburg University Press, 2000., str. 99-118., 106.

13 Halliwell, Stepen, The Aesthetics of Mimesis. Ancient Texts and Modern Problems, Princeton University Press, Princeton, 2002., str. 70-71.
} 
svojstvenosti, ${ }^{14}$ kako to da najveći deo tradicije razumevanja umetnosti i lepog stoji pod znakom Platonovog razumevanja mimezisa, te se neprestano kreće u krugu odbijanja i obnove istog? Ako Platon ne uspeva da do kraja odredi mimezis, kako onda da neka od njegovih pozitivnih određenja mimezisa uzeta izolovano ${ }^{15}$ uslovljavaju povest razumevanja umetnosti i lepog, a da to nije slučaj sa neodređenošću kao načinom „određenja” mimezisa? U čemu se sastoji Platonova smicalica? Zašto ova zbrka određenja mimezisa nije prosto razumljena kao šala komediografskog mimetičara Platona ili, pak, ozbiljno kao sam način mišljenja mimezisa u njegovoj nesvojstvenosti? U čemu se sastoji lukavstvo Platonovog uma kojim on skriva neuhvatljivost mimetičke umetnosti neprestano vladajući nad povešću razumevanja iste?

Kao što je poznato, Platon neprestano govori o slikama i slikovnosti, istovremeno neprestano govoreći jezikom slike. Ovaj neprestani govor slikom o slici dolazi od uznemirenosti i uzdrmanosti samom prirodom slike, ili opštije prirodom prikaza. U tom pogledu možemo reći da je Platonovo iskustvo mišljenja određeno kao iskušavanje slike, tj. da je Platonovo mišljenje iskušenje koje sobom nosi prikaz.

Dato iskustvo slike reflektovano je u Platonovom promišljanju mimezisa. Suštinsko u Platonovom iskušavanju mimezisa jeste sledeća dvostrukost: nešto se prikazom izdaje za nešto, a dato izdavanje može biti razumljeno kao da je ono što se prikazuje podražavanjem tu ili da je, sa druge strane, tu takoreći prazna slika ili prazan prikaz - slika koja ne upućuje ni na šta van sebe, slika koja ostaje pri sebi odbijajući u konačnom odnos sa idejom, pa bio on i posredovan preko pojedinačne stvari koja ima unutrašnji odnos sa idejom. Drugim rečima, Platonovo iskustvo mimezisa je iskustvo suštinske ambivalentnosti slike ili prikaza. ${ }^{16}$ Istu Platon najjasnije

14 Up. Lacoue-Labarthe, Philippe, "Typography”, u: Typography. Mimesis, philosophy, politics, prev. E. Donato, Harvard University Press, London, 1989., str. 43-138, 115-116, 126-127.

${ }^{15}$ Eugen Fink se u kritici Platonovog pojma mimezis isključivo drži slike ogledala iz 10. Knjige Države (Fink, Eugen, Igra kao simbol svijeta, prev. D. Domić, Demetra, Zagreb, 2000., str. 112-124).

16 Deleuze, Gilles, „Platon i simulakrum”, u: Logika smisla, prev. M. Gregorić, Sandorf \& Mizantrop, Zagreb, 2015., str. 228-238, 230. 
eksplicira kroz razliku umeća stvaranja slika u dijalogu Sofist preko razlike

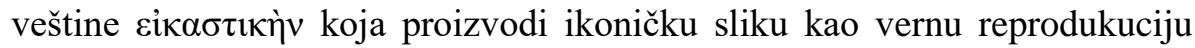

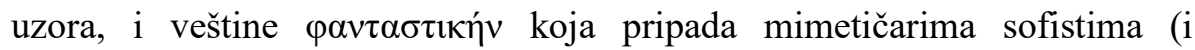
umetnicima) i koja proizodi prividnu sliku ili fantazmu. ${ }^{17}$

Platonovo suočavanje sa ambivalentošću prikaza uvek se sastoji u pokušaju da se fakt slike kao fantazme ili eidolona nekako kontroliše. Platonova strategija savladavanja fantazmatičkog prikaza u osnovi ima dva oblika, koji imaju jedinstvenu intenciju. Naime, u oba pravca kritike fantazmatičkog prikaza Platon dati prikaz nastoji da kontroliše putem ideje kao onoga prvog, iako fantazma upravo odbija mogućnost da ideja bude ono merodavno. U prvom slučaju, unutar kritike pesništva u 10. knjizi Države Platon fantazmatički model nastoji da kontroliše tako što pokušava da ga integriše unutar odnosa ideja-pojedinačna stvar. ${ }^{18}$ Ipak, svest o tome da fantazmatički model odbija mogućnost svođenja na trostruku udaljenost od ideje vodi Platona u poznim dijalozima ka izgradnji drugog oblika kritike, kritike koja neće poći od pretpostavke da za svet fantazme postoji nešto takvo kao što je ideja, ili u krajnjem slučaju, ono Jedno. Tako Platon u Teetetu kroz kritiku Protagore i unutar poslednja dva ispitivanja druge pretpostavke ,ako jedno nije” u Parmenidu ne polazi od prethodno pretpostavljenog odnosa ideja-pojedinačna stvar u želji da mimetički prikaz svede na kopiju kopije, već prihvata tezu datog sofističko-pesničkogfantazmatičkog modela, tj. tezu da nema onoga po sebi - da nema onoga Jednog. ${ }^{19}$

Iako Platon u ovom slučaju nastoji da izloži ontologiju sveta fantazme koji je određen odsustvom onoga po sebi, on dato čini polazeći od iste intencije kao i u slučaju prvog oblika kritike. Naime, Platon izlaže dati svet lišen onoga Jednog polazeći od njega samog, ali samo zato da bi ga sada pokazao kao samoprotivrečnog i kako bi ga time lišio svake pretenzije. Međutim, postavlja se pitanje da li mimetički svet fantazma i eidolona ne postoji time što logički nije moguć? Nije li upravo temeljna odlika fantazmatičkog modela koji određuje mimetičku umetnost odbijanje onih

\footnotetext{
${ }^{17}$ Plat. Soph. 235d-236d

18 Plat. Rep. 596a-c

${ }^{19}$ Plat. Theaet.152d-186a, Parm. 164b5-166c2.
} 
pretpostavki koje su prve za filozofski logos? Da li je time Platon svet fantazme lišio njegovog postojanja i da li ga je lišio njegove faktičke snage i njegovih realnih efekata? Naprotiv, krajnji rezultat Platonovih napora upravo je priznanje postojanja onoga što odbija odnos sa idejom i Jednim. Mimetički fantazam opstaje uprkos svim zamkama koje mu postavlja platonička ontologija. ${ }^{20}$

Platon ne uspeva da kontroliše neodlučivost prirode prikaza - da li kroz prikaz prosijava sama stvar ili je prikaz puki fantazam? Međutim, Platonovo rešenje sastoji se u postavljanju igre kojom se nekontrolisanost mimetičkog fantazma prikriva i pada u zaborav. Naime, Platon postavlja igru koja određuje dalju povest razumevanja mimezisa i njenu dinamiku i koja se sastoji u tome što je dati problem zamaglio izmeštanjem borbe u drugo područje. Platon to čini na način da poprište borbe oko neuhvatljive prirode mimetičkog prikaza zamenjuje poljem borbe dve koncepcije istine kojima se istovremeno razumeva mimezis. Time Platon za svoju potonju tradiciju uvlači mimezis unutar područja nadmetanja dve koncepcije istine. Datim gestom je nekontrolisana priroda fantazme, koja ne poznaje nikakvu istinu, zaboravljena u korist borbe istine kao ispravnosti ili tačnosti i istine u smislu

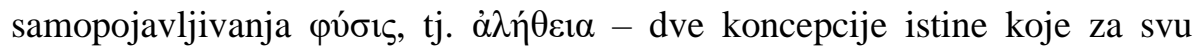
potonju povest grade dva modela razumevanja mimetičke umetnosti. ${ }^{21} \mathrm{Od}$ datog trenutka svako odbacivanje mimetičkog karaktera umetnosti i svaka potonja obnova mimezisa kao adekvatnog pristupa umetnosti kreću se unutar unapred uspostavljene platoničke igre dve koncepcije istine.

$\mathrm{U}$ datom počiva tajna Platonove vladavine nad neuhvatljivom prirodom mimezisa: time što je igru izmestio u područje sukoba dve koncepcije istine Platon je odredio dinamiku povesti razumevanja mimezisa, a da pri tome tajna fantazme ostane skrivena. Sva potonja povest

${ }^{20}$ Delez (Gilles Deleuze) drži da pošto Platon ne raspolaže do kraja razvijenim kategorijama predstave (što se događa tek sa Aristotelom) on fantazmu ili simulakrum progoni na temelju odluke (moralne), ali da upravo time,$\ldots$. neprijatelj grmi, po čitavom platonističkom svetu razlika se opire njegovom jarmu..." (Delez, Žil, Razlika i ponavljanje, prev. I. Milenković, Fedon, Beograd, 2009., str. 212).

${ }^{21}$ Up. Derrida, Jacques, "The Double Session", u: Dissemination, prev. B. Johnson, The Athlone Press, London, 1981., str. 173-286, 192-193. Derida, Žak, Bela mitologija, prev. M. Radović, Bratstvo-Jedinstvo, Beograd, 1990., str. 40-41. 
razumevanja umetnosti kretaće se unutar Platonovog začaranog kruga uspostavljanja mimezisa kao imitacije ili odslikavanja stvarnosti, kritike tako razumljene mimetičke umetnosti, te uspostavljanja mimezisa kao samoprikazivanja bića, i tako u krug.

\section{II}

Gadamer (Hans-Georg Gadamer) u izgradnji filozofske hermeneutike polazi od fenomena umetnosti kao odlikovanog fenomena, čijom analizom uspostavlja sve ključne pojmove koje će kasnije pokazati kao važeće za razumevanje kako povesne predaje, tako i samog fenomena jezika. ${ }^{22}$ Kroz kritiku onoga što naziva „estetskom svešću” koja umetničko delo zahvata pre svega preko pojma genija i doživljaja, svodeći ga na puki estetski predmet i lišavajući ga njegove istinosnosti, ${ }^{23}$ Gadamer nastoji da vrati umetničko delo svetu iz kojeg ono izrasta. Rečju, da mu vrati njegov karakter svetovnosti koji nam omogućava da učestvujemo u spoznaji koju ono otvara. ${ }^{24}$ Pri tome, ne samo da je većina ključnih pojmova koje ovde Gadamer izgrađuje vezana za već spomenutu Platonovu opsesivnost jezikom slike (Bild, Bildung, Appbild, Urbild, Vorbild, Gebilde), i ne samo da Gadamer za sebe tvrdi da je platoničar, ${ }^{25}$ već se Gadamer ekplicitno u izgradnji onoga što Gronden (Jean Grondin) naziva njegovom ,antiestetikom” ${ }^{26}$ vraća platonističkoj tradiciji: „Da bih se oslobodio pojma estetskog, koji odgovara građanskoj religiji obrazovanja, a ne da bih zastupao klasicističke ideale, ja sam u svoja istraživanja ubacio 'klasične' pojmove kao sto su 'mimeza' ili 'reprezentacija'. To je shvaćeno kao neka

\footnotetext{
${ }^{22}$ Up. Tatalović, N., „Gadamerova hermeneutička ontologija”, Arhe, IX, 17 (2012), str. 139-153.

${ }^{23}$ Gadamer, H.-G., Istina i metoda, str. 125.

${ }^{24}$ Ibid., str. 127.

25 Gadamer, H.-G., "Einleitung”, u: Die Lektion des Jahrhunderts. Ein philosophischer Dialog mit Riccardo Dottori, Lit Verlag, Münster, Hamburg, London, 2002., str. 3-21, 6.; “A Conversation With Hans-Georg Gadamer”, Method. Journal of Lonergan Studies, 1990, intervju (Michael Baur), str. 1-13, 6.

${ }^{26}$ Gronden, Žan, Uvod u filozofsku hermeneutiku, prev. E. Peruničić, Akademska knjiga, Novi Sad, 2010. str. 164.
} 
vrsta recidiva u jedan platonizam, koji je moderno shvaćanje umjetnosti definitivno prevazišlo. I to mi ne izgleda baš tako jednostavno." 27

Međutim, u pogledu na prethodno istaknutu višestrukost mimezisa $u$ Platonovom mišljenju, postavlja se pitanje koji smisao mimezisa Gadamer rehabilituje? Tačnije, ako je neodlučivost statusa mimetičkog prikaza kod Platona izmeštena $\mathrm{u}$ područje sukoba dve koncepcije istine - istine kao

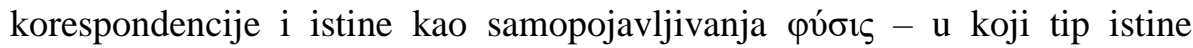
Gadamer smešta mimetički karakter umetničkog dela? Eksplicitan odgovor na prethodno pitanje nalazimo u tekstu „Pesništvo i mimezis”, gde Gadamer kritikuje Platonov napad na mimetičku umetnost preko teze o trostrukoj udaljenosti prikaza od bića koja stoji pod znakom istine kao korespondencije, tvrdeći da je time Platon preokrenuo suštinu umetničkog podražavanja. Naravno, odatle Gadamer, za razliku od Finka (Eugen Fink), ne odbacuje platonistički mimezis u celini, već zaključuje sledeće: „Da tamo gde govorimo o umetnosti suštinu prikazivanja ne čini razlika bića prikaza i prikazanog, nego puna identifikacija sa prikazanim, Platon je jasno priznao na drugim mestima." ${ }^{28}$ Dato znači da Gadamer polazi od platonističkog

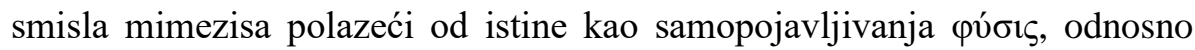
razvoja Platonove ideje o sijanju lepog koja ide preko Plotina (posredovana hrišćanskim učenjem o utelovljenju) do Hegela, kao ključnih mislilaca za Gadamerovu rehabilitaciju mimezisa. ${ }^{29}$

Mimezis za Gadamera, u njegovom ,izvornom” smislu, ne znači nešto što dolazi nakon nečega što je već znano, već znači dovođenje nečega do prikaza (Darstellung) tako da je ono prisutno u punini vlastitog smisla: „....smisao mimezisa sastoji jedino $\mathrm{u}$ tome da nešto pusti da postoji... Svoje istinsko ostvaranje svako prikazivanje nalazi ni u čemu drugom do u tome da

\footnotetext{
${ }^{27}$ Gadamer, H.-G., Istina i metoda, str. 609.

${ }^{28}$ Gadamer, Hans-Georg, „Pesništvo i mimezis”, prev. S. Radojčić, u: Filozofija $i$ poezija, Službeni list SRJ, Beograd, 2002, str. 33-38, 36.

${ }^{29}$ Gadamer, Hans-Georg, „Riječ i slika - 'tako istinito, tako zbiljsko”,, prev. S. Bosto, u: Čitanka, Matica hrvatska, Zagreb, 2002., str. 198-228, 217. Gadamer, H.G., Istina i metoda, str. 524. O odnosu Hegelove i Gadamerove misli vidi: Pippin, Robert B, “Gadamer's Hegel”, u: Gadamer's Century. Essays in Honor of HansGeorg Gadamer, J. Malpas, U. Arnswald, J. Kertscher (ur.), The MIT Press, Cambridge, 2002., str. 217-238.
} 
prikazano zaista stvarno postoji u prikazivanju". ${ }^{30}$ Za Gadamera mimezis jeste praodnos (Urverhältnis), ${ }^{31}$ unutar kojeg se ne događa podražavanje (Nachahmung), već je na delu preobražaj (Verwandlung) kao stupanje prikazanog prikazom u istinu. Unutar mimezisa je na delu ono što će Gadamer nazvati „estetsko nerazlikovanje” (ästhetische Nichtunterscheidung), gde nije moguće napraviti razliku onoga što se prikazuje i njegovog prikaza. Ako prethodno rečeno čitamo Delezom (Gilles Deleuze), tada se dodatno potvrđuje Gadamerova misao kao onoga koji pripada tradiciji platonizma, koja preko neoplatonizma svoj maksimum doseže u Hegelovom „dvostrukom odbijanju” razlike stvari po sebi i pojave, nasuprot Ničeovom ,preokretanju platonizma” koje afirmiše potisnutu moć fantazme ili simulakruma. ${ }^{32}$

Mimezis za Gadamera nije mišljen kao prikaz koji referira na nešto prethodno kao svoj uzor (Urbild), već da je sama stvar u svom prikazu ono što jeste u punom smislu. U pogledu na prethodno rečeno, Gadamer smatra da se putem grčkog pojma mimezisa i dalje može misliti umetnost, i povodom toga kaže sledeće: ,,... onaj ko misli da se umetnost ne može više primereno da misli pojmovima Grka, taj ne misli dovoljno grčki - i ne misli dovoljno dobro." 33 Prethodno znači da se pojam prikaza (Darstellung) mora oštro razlikovati od pojma odslikavanja (Abbildung). Ono što važi za odslikano jeste da ono nema vlastiti bitak. Odslikano iscrpljuje svoje biće time da nestane u pojavi pralika. ${ }^{34}$ Kao primer odslikavanja, Gadamer isprva navodi sliku u ogledalu jer slika u ogledalu nema bitak za sebe, ono jeste samo ukoliko se nešto u njemu oslikava i ukoliko neko u njega gleda. Dato nije ništa drugo nego jedna strana platonovski razumljenog mimezisa $u$ pogledu na istinu kao korespondenciju koja dominira kritikom mimetičke umetnosti u 10. knjizi Države. Međutim, čak ni ogledalo, drži Gadamer, nije dobar primer odslikavanja, jer slike u ogledalu ima samo kada ima nečega drugog, a odslik neće da bude ničeg drugog, već da on sam identifikuje ono

\footnotetext{
${ }^{30}$ Gadamer, H.-G., "Pesništvo i mimezis", str. 35.

${ }^{31}$ Gadamer govori o mimische Urverhältnis (Gadamer, H.-G., Istina i metoda, str. 143, 145; "Pesništvo i mimezis", str. 37).

${ }^{32}$ Deleuze, G., „Platon i simulakrum”, str. 228.

${ }^{33}$ Gadamer, H.-G., ,Pesništvo i mimezis”, str. 37.

${ }^{34}$ Gadamer, H.-G., Istina i metoda, str. 168.
} 
što jeste. Stoga bolji je primer odslika slika u pasošu koja nema nikakavu drugu funkciju do da nestane u onome što ona identifikuje. ${ }^{35}$

Za razliku od pojma odslika koji izražava jednu stranu platonovskog razumevanja mimezisa, Gadamer vlastiti pojam mimezisa gradi preko Platonovog razumevanja mimezisa izgrađenog na ideji ikoničke slike koja stoji u jedinstvu sa uzorom. U razlici spram odslikanog, slika (Bild) nema svoje određenje u prethodno spomenutom samoukidanju. Slika nije sredstvo, jer se u njoj prikazuje prikazano. ${ }^{36} \mathrm{Za}$ razliku od odslikanog, bitak slike nije nešto što nestaje, već nešto što se ističe kako bi se onome odslikanom omogućio da bude. Bitak slike je prikazivanje, i to je upravo ono što slici daje njen samostalni bitak. Slika, po Gadameru, prikazuje nešto što ne može da se vidi mimo datog prikazivanja, upravo je to odlika slike. Slika o praliku koji prikazuje govori nešto što inače nije vidljivo. ${ }^{37}$ Gadamer ovaj identitet slike i onoga u slici prikazanog naziva „magičnom čarolijom slike” (der magische Bildzauber) koja prati sliku od njene praistorije i koja i danas, uprkos svim diferenciranjima, pripada iskustvu slike. Ovaj magični identitet (der magischen Identität) slike i onoga slikom prikazanog pripada onome što Gadamer naziva nepovredivošću slike, njenom svetošću (Heiligkeit). ${ }^{38}$ Ovako razumljena ontologija slike, odnosno ovako razumljena priroda prikaza, svedoči o tome da Gadamer stoji pri onome što Valter Benjamin određuje kao premoderno iskustvo umetničkog dela, a što i sam Gadamer eksplicitno potvrđuje u tekstu „Aktuelnost lepog”, artikulišući ovde svetost umetničkog dela kao njegovu jedinstvenost i nezamenjivost, zaključujući rečima da je dato Benjamin nazvao aurom umetničkog dela. ${ }^{39}$

Kada je u pitanju slika, kao što smo rekli, prikaz ostaje bitno vezan za pralik koji je u prikazu slike prikazan. Naravno, ovde ne treba razumeti da

35 „Odslikano ukida sebe samo u tom smislu što fungira kao sredstvo i što, kao svako sredstvo, postizanjem svoje svrhe gubi funkciju. Ono je za sebe, da bi se tako ukinulo. Ovo samoukidanje odslikanog je intencionalni momenat na bitku samog odslikanog."'(Gadamer, H.-G., Istina i metoda, str. 168).

${ }^{36}$ Gadamer, H.-G., Istina i metoda, str. 169.

${ }^{37}$ Ibid., str. 170.

${ }^{38}$ Ibid., str. 169.

${ }^{39}$ Gadamer, Hans-Georg, "Die Aktualität des Schönen. Kunst als Spiel, Symbol und Fest”, u: Gesammelte Werke, Bd. 8, Mohr Siebeck, Tübingen, 1993, str. 94-142, 124. 
je time što je slika prikaz pralika ona onda nešto bićem manje od pralika koji prikazuje. Slika nije puko umanjenje bitka. Po Gadameru, samostalna stvarnost slike zapravo govori o tome da se sam pralik prikazuje u prikazu slike, odnosno to je njegovo samoprikazivanje. Obrnuto od odslikavanja, slika govori o tome da je sam pralik upućen na sliku, odnosno na vlastiti prikaz. Dakle, prikazivanje pralika u slici nije nešto spoljašnje samom praliku, već je sam proces kretanja života pralika. Takođe, nasuprot odslikavanju, sliku, po Gadameru, određuje porast bitka (Zuwachs an Sein) slika je nešto više nego puko odslikano, ona pokazuje pralik na način koji je nezamenjiv. ${ }^{40}$

Funkcija lepog se kod Platona, po Gadameru, sastoji u tome da premosti horizmu između ideje i pojedinačne pojave. ${ }^{41}$ Lepo nikada ne može biti odvojeno od svoje pojave, odnosno Platon određuje bit lepog u pojavljivanju, prosijavanju. ${ }^{42}$ Međutim, Gadamer takođe ističe da Platon neprestano govori o tome da su pojave koje sudeluju u lepom samo manje ili više lepe, da nikada nisu čista lepota i da su time „onečišćene”. ${ }^{43}$ Prethodno rečeno ukazuje na to da kod Platona, kao što to tvrdi Hajdeger (Martin Heidegger), još uvek nije na delu platonistički (u Hajdegerovoj upotrebi te reči) rascep biti i pojave, ali da je ipak na delu udaljenost ideje i pojave koja određuje Platonovo mišljenje mimezisa $u$ svim njegovim varijacijama. ${ }^{44}$ Upravo u pogledu na prethodno rečeno, ideja da je prikaz sam način kretanja života pralika, te da nije njegovo opadanje, već izraz njegovog bogatstva $\mathrm{i}$ preobilja, iako dolazi iz tradicije platonizma, ne dolazi, po Gadameru, neposredno od samog Platona, već datu mogućnost mišljenja otvara tek Plotin, gde je slika ontološki razumljena kao emanacija pralika: „Time se očituje nešto čega stvarno nije bilo u Platonovoj filozofiji logosa. Pojam emanacije u novoplatonizmu sadrži nešto više nego što je fizički fenomen isteka (Ausfließens) kao procesa kretanja. To je slika izvora (Quelle), koja se

\footnotetext{
${ }^{40}$ Gadamer, H.-G., Istina i metoda, str. 170.

${ }^{41}$ Gadamer, H.-G., "Die Aktualität des Schönen. Kunst als Spiel, Symbol und Fest", str. 106.

${ }^{42}$ Plat. Phaedrus, 250b-d.

${ }^{43}$ Gadamer, Hans-Georg, „Platon kao portretist”, prev. S. Bosto, u: Čitanka, Matica hrvatska, Zabgreb, 2002., str. 235-256, 252.

${ }^{44}$ Hajdeger, Martin, Niče, I, prev. B. Zec, Fedon, Beograd, 2009, str. 208-220.
} 
postavlja prije svega. U procesu emanacije ono što iz nečega izvire, to Jedno, ne biva time oskudnije." ${ }^{45}$

Odnos prikaza i onoga prikazanog, polazeći od neoplatoničke ideje emanacije, omogućava Gadameru da prikaz ne misli kao uniženje prikazanog, već kao emanizovani suvišak (Überfluß). Ovaj gest neoplatonizma, po Gadameru, uništava grčku ontologiju supstancije i zasniva „pozitivni rang bitka slike”, gde ono Jedno ne postaje manje onda kada biva prikazano nekim od svojih likova, tj. onda kada iz njega ističe $($ Ausflu $\beta)$ ono mnogo, već upravo suprotno: Jedno time postaje više. ${ }^{46}$ Datim neoplatonovskim gestom događa se, drži Gadamer, ontološki obrat relacije pralika i prikaza, unutar kojeg slika stiče samostalni status koji povratno deluje na sam pralik. Neoplatonizam time otvara mogućnost ostvarivanja onoga što Gadamer, zajedno sa Hegelom, misli kao spekulativno jedinstvo slike i pralika (stvari po sebi i pojave), gde pralik postaje ono što jeste tek u svom prikazu. ${ }^{47} \mathrm{U}$ pogledu na neoplatonističko nasleđe, prikaz se može razumeti i kao izraz (Ausdruck) Jednog. Nemačku reč Ausdruck, koja svoje poreklo, po Gadameru, ima u nemačkoj mistici i koja u 18 . veku potiskuje pojam podražavanja, ${ }^{48}$ treba vratiti metafizičkom smislu koji su uspostavili neoplatoničari i koji stoji u blizini mimezisa. Za Gadamera termin izraz ne znači znak koji referira na nešto unutrašnje, već da je u izrazu ono izraženo tu. Dati ontološki smisao izraza sačuvan je po Gadameru kod Spinoze i kod Hegela, koji izraz kao prikaz razume kao ispoljavanje koje određuje samu suštinu duha. ${ }^{49}$

\section{III}

Spekulativno jedinstvo prikaza i onoga prikazanog, čiju mogućnost otvara neoplatoničko mišljenje, Gadamer detaljno razvija kroz izgradnju pojmova igre (Spiel) i preobražaja u tvorevinu (Verwandlung ins Gebilde),

\footnotetext{
${ }^{45}$ Gadamer, H.-G., Istina i metoda, str. 469.

${ }^{46}$ Ibid., str. 170.

${ }^{47}$ Ibid., str. 171.

${ }^{48}$ Up. Popović, U., „Lepe umetnosti i podražavanje: Bateovo određenje modernog pojma umetnosti”, Arhe, 14, 28 (2018), str. 157-171.

${ }^{49}$ Ibid., str. 537-538.
} 
koji su samo dve strane eksplikacije istog mimetičkog praodnosa. Igra i

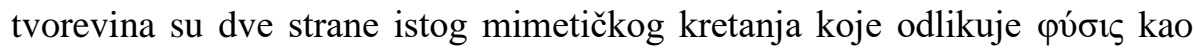
samopojavljivanje ili samoprikazivanje onoga što jeste. Ovaj dinamički i medijalni smisao mimezisa, kako ističe Švajker (William Schweiker), omogućava Gadameru da napusti ideju mimezisa kao imitiranja nalik ogledalu i otvara mišljenje mimezisa kao samoraskrivanja sveta. ${ }^{50}$ Iako Gadamer kaže da mimezis treba misliti unutar „sveobuhvatnog horizonta

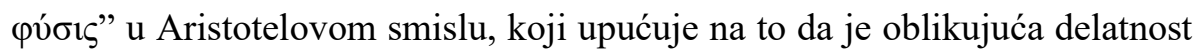
prirode ostavila slobodan prostor ljudskoj produktivnoj delatnosti, ${ }^{51}$ on zapravo u razumevanju umetničkog dela kao samoprikazivačke igre polazi

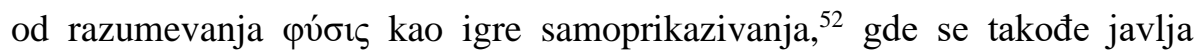
paralela sa Plotinovim mišljenjem.

Pojam igre sam po sebi nije pojam koji je nov za estetiku; on je, kod Šilera i Kanta, imao ključnu ulogu u izgradnji onoga što Gadamer naziva „subjektivističkom estetikom”. Nasuprot devetnaestovekovnoj estetici, Gadamer pod igrom ne razume duševno raspoloženje stvaraoca niti onoga koji uživa u umetničkom delu. Gadamerov pojam igre ne smera na slobodu subjekta, već „na sam način bitka umetničkog dela”. ${ }^{53}$ Značaj pojma igre za razumevanje umetničkog dela dolazi odatle što iskustvo umetnosti po Gadameru preobražava onoga koji iskušava umetničko delo. Drugim rečima, subjekt umetničkog dela nije naša subjektivnost i njen doživljaj, već samo umetničko delo koje opstaje i istrajava kroz naše iskušavanje istog, kao što igra ima svoju strukturu koja je nezavisna od svesti onih koji je igraju, iako, kroz igranje igrača dolazi do ispunjenja vlastitog bića. Dakle, Gadamer razlikuje samu igru od načina držanja onoga koji igru igra, tj. nastoji da misli igru ne polazeći do subjekta koji igra.

\footnotetext{
${ }^{50}$ Schweiker, William, Mimetic Reflections. A Study in Hermeneutics, Theology, and Ethics, Fordham University Press, New York, 1999., str. 45.

${ }^{51}$ Gadamer, H.-G., "Die Aktualität des Schönen. Kunst als Spiel, Symbol und Fest", str. 104.

$52, \ldots$ priroda i umjetnost stoje međusobno bliže negoli plansko proizvođenje proizvoda koji nastaju u radionici. Naš jezik govori o organskom jedinstvu u prirodi i umjetnosti.” (Gadamer, H.-G., „Riječ i slika - 'tako istinito', tako zbiljsko”,, str. 221).

${ }^{53}$ Gadamer, H.-G., Istina i metoda, str. 131.
} 
Najčešće razumevanje igre polazi od suprotnosti igre i ozbiljnosti, gde se ova poslednja razume kao ona koja je odlikovana izvršavanjem određene svrhe, što vodi razumevanju igre kao nečega što nije ozbiljno i što je lišeno svrhovitosti. Međutim, iako igra nema neku izvan sebe „ozbiljnu” svrhu, to, po Gadameru, ne znači da unutar igre ne postoji nikakvo svrhovito kretanje i time i ozbiljnost igre, naprotiv. Igra je igra samo ozbiljnošću držanja pri igranju iste, čime se ispunjava njena samosvrhovitost. ${ }^{54}$

$\mathrm{U}$ eksplikaciji pojma igre Gadamer polazi od miga jezika. Mi govorimo, ističe Gadamer, o igri svetla, suigri udova, igri snaga, igri reči itd. Jezik ovde igru pokazuje kao „neko kretanje tamo-amo” koje nije određeno postizanjem određenog cilja. U pogledu na prethodno, kretanje igre je, po Gadameru, određeno jedino $\mathrm{u}$ tome da se „obnavlja $\mathrm{u}$ stalnom ponavljanju", 55 tj. suštinsko za igru jeste prinavljajuće obnavljanje igre same, a ne onaj koji igru igra. Igra je, dakle, za Gadamera ,proces kretanja kao takvog" i prvotni smisao igre ne upućuje na neki njen podmet, već na čisto medijalni smisao igre. ${ }^{56}$ Rečju, subjekt igre je sama igra.

Jedina svrha igre je samoprikazivati se, ali pri tome Gadamer ističe nešto što je od suštinskog značaja za razumevanje njegove rehabilitacije mimezisa - naime, da je „samoprikazivanje univerzalni aspekt bitka prirode". ${ }^{57}$ Time se potvrđuje ono što smo prethodno istakli, da Gadamer

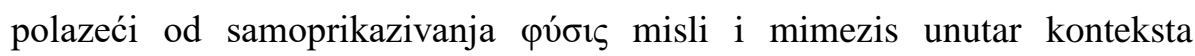
samoprikazivačkog karaktera umetničkog dela. Gadamer ističe značaj

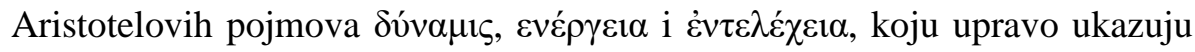
na ono što on misli pod pojmom izvršenja, tj. da izvršenje igre ima bitak u

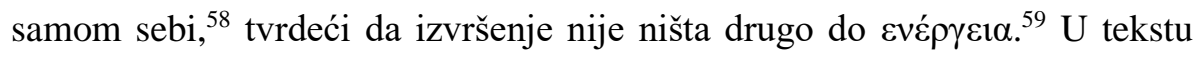
„Aktualnost lepog” Gadamer dato formuliše na sledeći način: „Ono što

\footnotetext{
${ }^{54}$ Ibid., str. 132.

55 Ibid., str. 133.

${ }^{56}$ Gadamer, H.-G., Istina i metoda, str. 134. Pored toga što igra nije kretanje ka nekoj određenoj svrsi, niti je ispunjenje određene namere, nju takođe određuje kretanje bez napora, ili kako Gadamer kaže: „Ona ide sama od sebe.” (Ibid., str. 135).

${ }^{57}$ Ibid., str. 138.

${ }^{58}$ Gadamer, H.-G., ,Riječ i slika - 'tako istinito, tako zbiljsko’”, str. 212.

${ }^{59}$ Ibid., str. 221. Gadamer, H.-G., Istina i metoda, str. 140.
} 
određuje ovo kretanje tamo-vamo sastoji se u tome da ni jedna od strana ovog kretanja ne predstavlja cilj u kome bi došlo do stajanja... Dato nam pruža mnogo toga za razmišljanje o pitanju umetnosti. Ova sloboda kretanja je takva da mora imati oblik samo-kretanja (Selbstbevegung). Izražavajući opštu misao Grka, Aristotel je već opisao samo-kretanje kao temeljni karakter (Grundcharakter) živih bića. Sve što je živo ima svoj izvor kretanja u sebi i ima oblik samokretanja. Time se igra pojavljuje kao samo-kretanje koje ne teži nekom određenom cilju ili svrsi koliko je kretanje kao kretanje, pokazujući tako reći fenomen ekscesa, koji znači samo-prikazivanje (Selbstdarstellung) bića života." ${ }^{60}$

U skladu sa prethodnim, Gadamer poredi umetničko delo sa organizmom, te dovodi u vezu Aristotelov pojam \&vé $\rho \gamma \varepsilon 1 \alpha$ sa Kantovim pojmom svrhovitosti bez svrhe kako bi odredio način umetničkog dela kao analogan načinu živog bića. ${ }^{61}$ Gadamerovo uključivanje Aristotelovih pojmova zarad objašnjenja načina života umetničkog dela, uz svest o značaju platonističkog nasleđa za njegovu misao, ne može a da opet ne nađe svoje adekvatno mesto upravo u Plotinovoj misli. Upravo će Kasirer (Ernst Cassirer) istaći da je neoplatonističko učenje o emanaciji ono sa kojim prvi put $\mathrm{u}$ povesti filozofije ,... stupa u punoj razgovetnosti odnos i misaona korelacija između biološkog i estetičkog problema, između organizma i ideje lepog." ${ }^{\circ 2}$ Tako Plotinova misao, kao specifična sinteza platonizma i aristotelizma, ne samo da je bogata figurama plesa kojima izražava način onoga živog, već sam život razume kao umetnički. Tako Plotin kaže sledeće: „Dakle, i ona bića koja ne poseduju (opažanje), i bilo šta što na koji god način učestvuje (u životu) neposredno je upojmljeno, to jest uobličeno, pošto delatnost koja pripada životu može da uobličava i pošto se ona kreće tako da uobličava. Prema tome, delatnost života je umetnička delatnost kao što se (na primer) kreće čovek koji pleše, jer, sam plesač sliči životu koji je na taj

\footnotetext{
${ }^{60}$ Gadamer, H.-G., "Die Aktualität des Schönen. Kunst als Spiel, Symbol und Fest”, str. 113-114.

${ }^{61}$ Ibid., str. 114.

${ }^{62}$ Kasirer, E., Kant. Život i učenje, prev. A. Buha, Hinaki, Beograd, 2006, str. 279280 .
} 
način umetnički, i njega pokreće umetnost, i pokreće ga na taj način pošto je sam život nekako takav." "63

Sa druge strane, shodno samom ponašanju igrača, po Gadameru, svako igranje jeste odigravanje, što znači pred sobom imati slobodu, odnosno stajati pred mogućnostima koje igra otvara. Naravno, ovde na delu nije polje beskrajnih mogućnosti, već mogućnosti koje igra isporučuje, i draž igre, po Gadameru, upravo dolazi od datog prostora mogućnosti koji treba da se proigra. Dakle, igrač nije toliko onaj koji iskušava, koliko je onaj koji je iskušan poljem mogućnosti koje mu igra otvara i unutar kojeg ga igra nastanjuje. ${ }^{64}$ Ovo proigravanje mogućnosti isporučenih igrom ukazuje na to da igra ne vrši neki sebi spoljašnji zadatak, već da je izvršenje zadatka koji igra postavlja prikazivanje same igre. ${ }^{65}$ Gadamerova teza o prevlasti same igre nad igračem, to da takoreći igra igra igrača, svoj eho takođe nalazi kod Plotina u sledećim rečima: „Ali, delovi (tela) plesača po nužnosti ne bi mogli biti istovetni u pojedinačnim plesnim figurama, budući da njegovo telo prati ples i prilagođava mu se, a od udova (njegovog tela) jedan je i opterećen a drugi opušten, jedan trpi napor a drugi se odmara u nekoj drugoj plesnoj figuri. Namera plesača je usmerena na nešto drugo, a (delovi njegovog tela) su aficirani sledeći ples, služe plesu i pomažu da se on dovrši u potpunosti... plesač nije izabrao da tako pleše." $" 66$

Dakle, u izvršenju igre koje bismo plotinovski nazvali ples, igra tek dolazi do svog bitka, odnosno ona postaje prezentna tek u i kroz sam čin izvršenja, a kako je subjekt igre sama igra, a ne igrač, tako je sam način bitka igre da dođe do vlastitog prikaza. Ovde je takođe interesantno da sam Plotin, govoreći o materiji koja se može misliti i kao mogućnost, kaže da ona može

${ }^{63}$ Plotin, Eneada III, prev. S. Blagojević, Književne novine, Beograd, 1984. str. 32 (Enn. III. 2. 16, 20-28).

${ }^{64}$ Ili kako Gadamer kaže: „Igra je ono što igrača drži u vlasti, što ga upliće i drži u igri." (Istina i metoda, str. 136).

65 „Umjetnost je u izvršenju... Ali, to znači: bitak umjetničkog djela niti je ono stvoreno niti stvar pogađaju pojmovi produkcije i reporodukcije sa strane primatelja. Štoviše, to ga razlikovanje upravo promašuje.” (Gadamer, H.-G., ,Riječ i slika "tako istinito, tako zbiljsko",, str. 217)

${ }^{66}$ Plotin, Eneada IV, prev. S. Blagojević, Književne novine, Beograd, 1984. str. 83 (Enn. IV. 4. 33, 11-25). 
uzeti najrazličitija obličja ,,.. kao što se plesač pretvara u sva (obličja)" ${ }^{67}$ Shodno jeziku tradicije, Gadamerovo razumevanje igre bi se, s obzirom na strukturni aspekt pravila kao prostora mogućnosti različitih pravaca izvršenja, uslovno rečno, moglo postaviti kao nadređenost oblika igrača kao

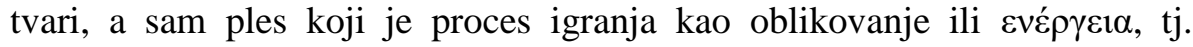
stupanje umetničkog dela u vlastiti oblik/prikaz preko (plesnog) izvršenja. Pored prethodnog, ranije pomenuta Gadamerova ideja da suština slike mišljene kao prikaz nije pad uzora, već da kao prelivanje uzora predstavlja porast bitka koji ne umanjuje sam uzor, nalazi eksplicitnu potvrdu kod Plotina $\mathrm{i}$ to uz istovremenu vezu sa figurom plesa. Naime, Plotin kaže sledeće: „U tom plesu (plesač) posmatra izvor života, izvor uma, načelo bića, uzrok dobra, koren duše. Sve to se izliva iz Njega tako što Ga ne umanjuje..." ${ }^{\text {68 }}$

Pored prethodno rečenog, igra kao prikazivanje za Gadamera je uvek prikazivanje za nekog - ,prikaz za”. ${ }^{69}$ Međutim, ovo prikazivati se nekome, ili biti ,prikaz za”, ne znači da je osnov igre mišljen u pogledu na onoga kome se igra prikazuje. ${ }^{70}$ Ako je fenomen igre vodilja razumevanja iskustva umetničkog dela, onda to znači da umetničko delo uvek jeste za nekog. Ako umetničko delo sebe odašilje ka nečijem razumevanju, dato ne znači da je subjekt koji razumeva, odnosno iskušava umetničko delo onaj koji konstituiše ono šta umetničko delo jeste. To da je umetničko delo kao igra uvek igra za, ovde za nečiju interpretaciju, ne znači, da je ono proizvedeno činom interpretacije, već da je u samu strukturu umetničkog dela uključeno to da je ono za nekog. Umetničko delo mišljeno kao igra jeste po sebi to da je za drugog. Kao i u prethodno razmatranom slučaju slike, i kod razumevanja umetničkog dela kao igre Gadamer ukida razliku koju postavlja

\footnotetext{
${ }^{67}$ Plotin, Eneada VI, prev. S. Blagojević, Književne novine, Beograd, 1984. str. 35 (Enn. VI. 1. 27, 20-21).

${ }^{68}$ Ibid., str. 224 (Enn. VI, 9. 9, 1-5)

${ }^{69}$ Gadamer, H.-G., Istina $i$ metoda, str. 138. „U konačnom, igra je time samoprikazivanje vlastog kretanja." (Gadamer, H.-G., "Die Aktualität des Schönen. Kunst als Spiel, Symbol und Fest", str. 104).

${ }^{70}$ Kako sam Gadamer kaže: „Otvorenost prema posmatraču spada, naprotiv, takođe u zatvorenost igre. Posmatrač vrši samo ono što je igra kao takva." (Gadamer, H.-G., Istina i metoda, str. 139).
} 
posmatrački odnos spram umetničkog dela i uspostavlja igrački odnos, gde posmatrač postaje igrač preko kojeg se igra odigrava dolazeći do vlastitog bitka. $^{71}$

\section{LITERATURA}

"A Conversation With Hans-Georg Gadamer", Method. Journal of Lonergan Studies, 1990, intervju (Michael Baur), str. 1-13.

Cassirer, E., "Eidos und Eidolon. Das Problem des Schönen und der Kunst in Platons Dialogen", u: Vorträge der Bibliothek Warburg, II. Vorträge 19221923 / I. Teil, (1924), str. 1-27.

de Man, P., „Retorika temporalnosti”, u: Problemi moderne kritike, Nolit, Beograd, 1975., str. 236-284.

Deleuze, G., „Platon i simulakrum”, u: Logika smisla, Sandorf \& Mizantrop, Zagreb, 2015., str. 228-238.

Delez, Ž., Razlika i ponavljanje, Fedon, Beograd, 2009.

Derida, Ž., „Ekonomimezis”, Treći program, br. 112 (2001), str. 175-208.

Derida, Ž., Bela mitologija, Bratsvo-Jedinstvo, Beograd, 1990.

Derrida, J., "The Double Session", u: Dissemination, The Athlone Press, London, 1981., str. 173-286.

Dostal, R., "Gadamer's Platonism: His Recovery of Mimesis and Anamnesis", u: Consequences of Hermeneutics. Fifty Years After Gadamer's Truth and Method, J. Malpas (ur.), Northwestern University Press, 2010., str. 45-65.

Else, Gerald F., “'Imitation' in the Fifth Century”, u: Classical Philology, Vol. 53, No. 2 (1958), str. 73-90.

Elsner, J., "Between Mimesis and Divine Power. Visuality in the Greco-Roman World", u: Visuality before and Beyond the Renaissance. Seeing as Others Saw, R. S. Nelson (ur.), Cambridge University Press, Cambridge, 2000., str. 45-66.

Fink, E., Igra kao simbol svijeta, Demetra, Zagreb, 2000.

Gadamer, H.-G., "Die Aktualität des Schönen. Kunst als Spiel, Symbol und Fest", u: Gesammelte Werke, Bd. 8, Mohr Siebeck, Tübingen, 1993, str. 94-142.

Gadamer, H.-G., "Einleitung", u: Die Lektion des Jahrhunderts. Ein philosophischer Dialog mit Riccardo Dottori, Lit Verlag, Münster, Hamburg, London, 2002., str. 3-21.

${ }^{71}$ Gadamer, H.-G., Istina i metoda, str. 140. 
Gadamer, H.-G., „Pesništvo i mimezis”, u: Filozofija i poezija, Službeni list SRJ, Beograd, 2002, str. 33-38.

Gadamer, H.-G., „Platon kao portretist”, u: Čitanka, Matica hrvatska, Zabgreb, 2002., str. 235-256.

Gadamer, H.-G., „Pohvala teoriji”, u: Pohvala teoriji, Oktoih, Podgorica, 1996., str. 5-25.

Gadamer, H.-G., „Riječ i slika - 'tako istinito, tako zbiljsko”, u: Čitanka, Matica hrvatska, Zagreb, 2002., str. 198-228.

Gadamer, H.-G., „Tekst i interpretacija”, u: Čitanka, Matica hrvatska, Zagreb, 2002., str. 165-197.

Gadamer, H.-G., Istina i metoda. Osnovi filozofske hermeneutike, Veselin Masleša, Sarajevo, 1978.

Gonzalez, F. J., "The Philosophical Use of Mimēsis", u: The Many Faces of Mimessis. Selected Essays from the 2017 Symposium on the Hellenic Heritage of Western Greece, Heather L. Reid, Jeremy C. DeLong (ur.), Parnassos Press, Sioux City, 2018., str. 23-36.

Gronden, Ž., Uvod u filozofsku hermeneutiku, Akademska knjiga, Novi Sad, 2010. str. 164.

Hajdeger, Martin, Niče, I, Fedon, Beograd, 2009.

Halliwell, S., "Plato and Painting", u: Word and Image in Ancient Greece, N. K. Rutter, B. A. Sparkes (ur.), Edinburg University Press, 2000., str. 99-118.

Halliwell, S., The Aesthetics of Mimesis. Ancient Texts and Modern Problems, Princeton University Press, Princeton, 2002.

Kasirer, E., Kant. Život i učenje, Hinaki, Beograd, 2006.

Keuls, E., Plato and Greek Painting, Brill, Leiden, 1978.

Kisiel, T., "Repetition in Gadamer's hermeneutics", u: The Late Husserl and the Idea of Phenomenology. Idealism-Realism, Historicity and Nature, A.T.Tymieniecka (ur.), D. Reidel Publishing Company, Dordrecht, 1972., 196-203.

Kjerkegor, S., Ponavljanje, Grafos, Beograd, 1982.

Koller, H., Die Mimesis in der Antike. Nachahmung, Darstellung, Ausdruck, A. Francke, Berne, 1954.

Lacoue-Labarthe, P., "Typography”, u: Typography. Mimesis, philosophy, politics, Harvard University Press, London, 1989., str. 43-138.

Melberg, A., "Repetition (In the Kierkegaardian Sense of the Term)", Diacritics, Vol. 20, No. 3 (1990), str. 71-87.

Melberg, A., Theories of mimesis, Cambridge Univerisity Press, New York, 1995.

Nightingale, A. W., Spectacles of Truth in Classical Greek Philosophy. Theoria in its Cultural Context, Cambridge University Press, New York, 2004. 
Pippin, R., “Gadamer's Hegel”, u: Gadamer's Century. Essays in Honor of HansGeorg Gadamer, J. Malpas, U. Arnswald, J. Kertscher (ur.), The MIT Press, Cambridge, 2002., str. 217-238.

Platonis Opera. Recognovit brevique adnotatione critica instruxit Ioannes Burnet. Toms I-V, Oxford, 1966.

Plotin, Eneada III, IV, VI, Književne novine, Beograd, 1984.

Popović, U., „Lepe umetnosti i podražavanje: Bateovo određenje modernog pojma umetnosti”, Arhe, 14, 28 (2018), str. 157-171.

Popović, U., „Platonova kritika umetnosti iz perspektive obrazovanja”, Arhe, VII, 13 (2010), str. 129-147.

Rausch, H., Theoria. Von ihrer sakralen zur philosophischen Bedeutung, Wilhelm Fink, München, 1982.

Ricoeur, P., “Temporal Distance and Death in History", u: Gadamer's Century. Essays in Honor of Hans-Georg Gadamer, J. Malpas, U. Arnswald (ur.), The MIT Press, Cambridge, 2002., str. 239-256.

Riker, P., Vreme i priča, I, IKZS, Sremski Karlovci, 1993.

Risser, J., "Hermeneutic Experience and Memory: Rethinking Knowledge as Recollection", Research in Phenomenology, Vol. 16 (1986), str. 41-55.

Schweiker, W., "Beyond Imitation: Mimetic Praxis in Gadamer, Ricoeur, and Derrida", u: The Journal of Religion, Vol. 68, No. 1 (1988), str. 21-38.

Schweiker, William, Mimetic Reflections. A Study in Hermeneutics, Theology, and Ethics, Fordham University Press, New York, 1999.

Tatalović, N., „Gadamerova hermeneutička ontologija”, Arhe, IX, 17 (2012), str. 139-153. 


\title{
NIKOLA TATALOVIĆ \\ University of Novi Sad, Faculty of Philosophy
}

\section{GADAMER'S "REPETITION" OF MIMESIS I}

\begin{abstract}
The research follows the basic characteristics of Gadamer's rehabilitation of the concept of mimesis, which is of crucial importance for the development of the whole of his project of philosophical hermeneutics. The research points to the underlying assumptions that guide Gadamer's return to the "original" sense of mimesis. Analyzing Gadamer's understanding of the notion of play, transformation into the structure and temporal character of a work of art, the research seeks to point out the fundamental dependence of Gadamer's notion of mimesis on the Platonic tradition, primarily Neoplatonism. Given the Platonic game of understanding of mimesis, which moves through the conflict of truth as correspondence and truth as self-showing of being, analyzes ultimately show that Gadamer returns to mimesis without actually repeating mimesis, and points to the need to abandon the notion of truth if indeed we want to repeat mimesis. The first part of the research, presented in this paper, aims to conduct most of the aforementioned analyzes in order to explain in detail in the second part of the research the previously pointed out conclusion regarding the character of Gadamer's notion of mimesis.
\end{abstract}

Keywords: Gadamer, mimesis, presentation, play, art, festival, repetition, theory

Primljeno: 26.2.2021. Prihvaćeno: 5.5.2021. 
